\title{
Российское право и международные стандарты об исполнении наказаний осужденных без изоляции от общества
}

Анисимов А.Л.*

\section{Задачи, цели и принципы уголовно-исполнительной политики}

Одним из направлений деятельности любого цивилизованного государства является политика в сфере борьбы с преступностью. В ней в концентрированном виде, как правило, определяются цели, принципы, стратегия, основные направления, формы и методы контроля государства за преступностью. Она должна выражать законные интересы граждан и обеспечивать защиту их прав и этих интересов, а также отражать интересы общества и государства.

Политика Российского государства в указанной сфере многопланова, ее условно можно разделить на политику в сфере предупреждения преступности, уголовную и уголовно-исполнительную. В то же время все направления этой политики едины с точки зрения целей, принципов и стратегии и тесно взаимосвязаны. При этом основные формы и методы реализации политики в различных сферах борьбы с преступностью не всегда имеют характер уголовно-правового воздействия.

Уголовно-исполнительная политика определяет цели, принципы, стратегию, направление деятельности государства, ее основные формы и методы при исполнении основных средств исправления, в том числе адаптации лищ, отбывающих наказание, и оказания им помощи.

Значительное влияние на уголовно-исполнительную политику оказывает экономическое состояние общества. Благополучное в экономическом отношении государство способно создать должную материальную базу для успешного выполнения стоящих перед ним целей по реализации этой политики. В условиях экономической нестабильности, обнищания населения создаваемый при этом разрыв между провозглашенными гуманистическими принципами и их реальным воплощением в итоге дискредитирует их.

\footnotetext{
'Анисимов Антон Леонидович - к.ю.н., доцент, прокурор отдела Управления Генеральной прокуратуры Российской Федерации, доцент Московского института международных экономических отношений (МИМЭО).
} 
Немаловажным фактором для реализащии уголовно-исполнительной политики, в частности касающейся исполнения наказания, является нравственное состояние общества, уровень его правового сознания. Последнее, как известно, обостряется с обострением социальных отношений в обществе, что неизбежно отрицательно влияет на формирование более жесткой уголовно-исполнительной политики. При таких обстоятельствах благие цели и принципы этой политики практически не реализуются.

Субъектами формирования и развития политики в сфере исполнения наказания в России являются Президент РФ и Федеральное Собрание РФ. В частности, Президент РФ закрепил стратегические и тактические основы развития уголовно-исполнительной системы, утвердив 13 января 1996 года Концепцию реорганизации уголовноисполнительной системы МВД России на период до 2005 г.

В Российской Федерации активно проводится правовая реформа, в том числе реформа законодательства, регулирующего исполнение уголовных наказаний.

Уголовно-исполнительный кодекс РФ (далее - УИК РФ), вступивший в силу 1 июля 1997 года, закрепил важнейшие положения уголовно-исполнительной политики Российского государства о направленности законодательства и практики его применения на решение задач первостепенной важности, в частности на нравственное совершенствование личности осужденного, его исправление. В этом смысле УИК РФ от ранее действовавших законоположений отличается гуманистической направленностью'. Его нормы ориентированы на международные стандарты обращения с осужденными и четкое определение правового статуса осужденных, их субъективных прав, законных интересов и обязанностей.

Новейший этап реформы утоловно-исполнительного законодательства и права связан с реализацией Россией рекомендаций Совета Европы, принятых при вступлении в эту организацию в 1996 г. В соответствии с ними с 1 сентября 1998 года уголовно-исполнительная система МВД России, исполняющая наказания в отношении большин-

' До принятия Уголовно-исполнительного кодекса РФ (1996 г.) исполнение и отбывание наказания регулировали нормативно-правовые акты бывшего СССР и РСФСР, в частности: Исполнительно-трудовой кодекс РСФСР, Положение о порядке и условиях исполнения в РСФСР наказаний, не связанных с мерами исправительно-трудового воздействия на осужденных, секретная инструкция МВД СССР о порядке исполнения смертной казни и другие многочисленные акты министерств и ведомств. 
ства осужденных, была передана в ведение Министерства юстиции РФ, т.е. выведена из подчинения карательного органа².

В соответствии с нормами Уголовно-исполнительного кодекса РФ был принят целый ряд подзаконных нормативно-правовых актов по вопросам исполнения наказания осужденных. К их числу, в частности, относится и рассматриваемая нами ниже в контексте современных международных актов, в том числе Совета Европы, и правил УИК РФ «Инструкция о порядке исполнения наказаний и мер уголовно-правового характера без изоляции от общества» ${ }^{3}$, утвержденная приказом Министерства юстиции РФ 12 апреля 2005 года № 38.

Указанная Инструкция прежде всего определяет организацию деятельности уголовно-исполнительных инспекций в соответствии с Положением об уголовно-исполнительных инспекциях, утвержденным постановлением Правительства РФ от 16 июня 1997 года № 7294, и «Общими положениями» ${ }^{5}$ этой Инструкции по исполнению наказаний в виде лишения права занимать определенные должности или заниматься определенной деятельностью, обязательных работ, исправительных работ, осуществлению контроля за поведением условно осужденных.

Следует отметить, что уголовно-исполнительные инспекции (далее - инспекции) являются учреждениями, исполняющими в соответствии с уголовно-исполнительным законодательством уголовные наказания в отношении лиц, осужденных без изоляции от общества.

Основными задачами инспекций являются:

а) исполнение наказаний в виде обязательных работ, лишения права занимать определенные должности или заниматься определенной деятельностью и исправительных работ;

${ }^{2}$ См. Указы Президента РФ № 1400 от 8 октября 1997 года и № 904 от 28 июля 1998 года.

${ }^{3}$ Текст см.: Российская газета. 2005. 11 мая.

${ }^{4}$ Текст см.: Российская газета. 1997. 25 июня. Данное Положение нами рассматривается с изменениями, внесенными постановлением Правительства РФ № 199 от 20 февраля 1999 года

" «Общие положения» разработаны, как это следует из содержания Инструкции, на основе ст. 23 Федерального закона от 23 марта № 53-Ф3 «О воинской обязанности и военной службе»; ст. 10, 11 Закона РФ от 18 апреля 1991 года № 1026-1 «О милиции»; ст. 21 Федерального закона от 24 июня 1999 года. № 120-Ф3 «Об основах системы профилактики безнадзорности и правонарушений несовершеннолетних»; ст. 70, 86 Уголовного кодекса РФ; ст. 393, 397, 399, 409 Уголовно-процессуального кодекса РФ; ст. 16, 20, 177 Угаловно-нсполнительного кодекса РФ. 
б) контроль за поведением условно осужденных, осужденных беременных женщин и женщин, имеющих малолетних детей (далее- осужденные женщины);

в) предупреждение преступлений и иных правонарушений лицами, состоящими на учете в инспекциях.

В соответствии с российским законодательством на инспекции возлагаются следующие основные обязанности:

- ведение учета осужденных;

- разъяснение осужденным порядка и условий отбывания наказаний;

- организауия и проведение воспитательной работы с осужденными клишению права занимать определенные должности или заниматься определенной деятельностью и к исправительным работам;

- согласование с органами местного самоуправления объектов для отбывания обязательных работ осужденными;

- направление при необходимости осужденных к исправительным работам в органы по вопросам занятости населения для трудоустpoücmea;

- контроль за поведением осужденных по месту работы, учебы и жительства, а также исполнением иии обязанностей и соблюдени'ем запретов, возложенных судом и инспекуией;

- выдача разрешений осужденным к исправительным работам на увольнение с работы по собственному желанию в период отбывания наказания и согласование вопроса с администрачией организачий, в которых они работают, о предоставлении им ежегодного оплачиваемого отпуска;

- проведение первоначальных мероприятий по розыску осужденных к исправительным работам, лишенных права занимать определенные должсности или заниматься определенной деятельностью, условно осужденных и осужденных женщин, местонахождение которых неизвестно;

- внесение в суды в установленном порядке представлений по вопросам дальнейшего отбывания наказания осужденным и освобождения от наказаний;

- выявление причин и условий, способствуючих совершению осужденными повторных преступлений, нарущению общественного порядка, трудовой дисуиплины и принятие мер по их устранению.

В свою очередь, инспекции имеют право:

- вызывать осужденных для разъяснения порядка и условий отбыва- 
ния наказания, проведения профилактических бесед, выяснения вопросов, возникающих в прочессе отбывания наказания, и прочих допущенных нарушений порядка и условий отбывания наказания;

- устанавливать обязанности и запреты для осужденных кисправительным работам, продлевать или сокращать их сроки и объеи;

- посещать осужденных по месту их нахождения, включая место жительства и работы, с челью контроля за поведением, соблюдением ими установленных обязанностей и запретов;

- выносить в установленном порядке постановления о приводе осужденных, состоящих на учете в инспекции и не являющихся по вызову в инспекчию без уважительных причин;

- проверять исполнение требований приговоров судов администрацией организачий, в которых работают осужденные к исправительным работам и лишению права занимать определенные должности или заниматься определенной деятельностью, а также органами, правомочными аннулировать разрешение на занятие определенной деятельностью, запрещенной осужденным;

- запрашивать от администрачии организачий, в которых работают осужденные, документы о проведенной работе с осужденными, их поведении, отночении к труду, принятых к ним мерах пооцрения и взыскания, а также сведения об отработанном осужденными времени;

- обращаться в органы местного самоуправления и прокуратуры, суды и организачии для решения вопросов, связанных с исполнением наказаний, и некоторых других.

Согласно п. 5 указанной выше Инструкции инспекции взаимодействуют с органами внутренних дел на основе разработки и осуществления совместных операций по контролю за поведением осужденных, соблюдением условно осужденными возложенных на них судом обязанностей, предупреждению преступлений и иных правонарушений, устранению причин и условий, способствующих их совершению, а также обмену соответствующей информацией. В этих целях инспекции:

- готовят и направляют в органы внутренних дел предложения и планы совместных мероприятий;

- принимают участие в мероприятиях, проводимых органами внутренних дел по проверке поведения осужденных по месту жительства и в общественных местах; 
- систематически направляют в органы внутренних дел информацию об осужденных, состояцих на учете.

\section{Международные стандарты об обращении с осужденными}

\section{без изоляции от общества}

Российские специалисты по уголовно-исполнительному праву классифицируют стандарты, содержащиеся в международных актах об обращении с осужденными, как минимум, по трем основаниям ${ }^{6}$ : a) масштабам действия; б) специализации; в) обязательности для государствприменителей.

По масштабам действия указанные стандарты подразделяют на две основные группы: универсальные и региональные

Универсальные - это стандарты, выработанные $\mathrm{OOH}^{8}$, а региональные-Советом Европы и иными региональными объединениями государств.

Подавляющая часть универсальных международных стандартов обращения с осужденными к мерам, не связанным с лишением свободы, сосредоточена в Минимальных стандартах ООН в отношении мер, не связанных с тюремным заключением (Токийских правил) $1990 r^{9}$.

Основное назначение стандартов рассматриваемой группы заключается в содействии рациональному использованию мер, не связанных с изоляцией от общества (тюремным заключением), как альтернативы лишению свободы.

При применении стандартов государствами - членами ООН рекомендуется руководствоваться следующими принципами: 1) обеспечить активное участие представителей общественности на всех стадиях реализации рассматриваемых мер; 2) создать соответствующее соотношение между правами осужденных, их жертв, интересами обще-

${ }^{6}$ Подробнее, например, см.: Уголовно-исполнительное право России: Учебник / Под ред. проф. В.И. Селиверстова. 2 изд. М., 2001. С. 519-531.

${ }^{7}$ См.: Зимин В.П., Зубов И.Н. Международное сотрудничество в области борьбы с преступностью и охраны общественного порядка. М., 1998. С. 16.

${ }^{8}$ Стандарты ООН в рассматриваемой сфере, к примеру, содержат следуюшие международные специализированные правовые акты: Минимальные стандартные правила обрашения с заключенными (1995 г.); Конвенция против пыток и других жестоких, бесчеловечных или унижающих достоинство видов обращения и наказания (1979 г.); Минимальные стандартные правила $\mathrm{OOH}$ в отношении мер, не связанных с тюремным заключением (Токийские правила) (1990 г.) и др.

${ }^{9}$ Об этом, например, см.: Уголовно-исполнительное право России / Под ред. проф. В.И. Селиверстова. М., 2001. С. 521-523. 
ственной безопасности и предупреждения преступности; 3) реализовывать стандарты с учетом национальных особенностей страны, состояния преступности и целей политики уголовного правосудия; 4) определить сравнительно широкий спектр мер в целях гибкого реагирования на характер и степень тяжести преступления, личность преступника с учетом интересов общества; 5) минимальное вмешательство со стороны органов исполнения наказания при применении соответствующих мер.

Рассматриваемые стандартные правила предусматривают следующий набор мер, не связанных с изоляцией от обшества (тюремным заключением):

- устные санкции: замечание, порицание, предупреждение;

- условное освобождение от ответственности;

- поражение в гражданских правах;

экономические санкции и денежные наказания в виде разовых и поденных штрафов;

- возвращение имущества жертве или постановление о компенсации;

- условное наказание или наказание с отсрочкой;

- условное освобождение из заключения и судебный надзор;

- постановление о выполнении общественно-полезных работ;

- направление в исправительное учреждение с обязательным ежедневным присутствием;

- домашний арест;

- любой другой вид обращения, не связанного с тюремным заключением;

- сочетание перечисленных выше мер.

В том случае, когда компетентными органами принято решение о наказании правонарушителя мерами воздействия без изоляции от общества, они должны быть практическими, по возможности немногочисленными и профилактируюшими опасность возвращения осужденного к преступной деятельности.

В Токийских правилах изложены также определенные требования, предъявляемые к режиму обращения; в частности, в рамках применяемых мер должны использоваться различные методы, в том числе индивидуальная работа, групповая терапия, программы по месту жительства, особое обращение с различными категориями осужденных. Рекомендуется всячески поошрять участие общественности в испол- 
нении мер, не связанных с изоляцией от общества (тюремным заключением), которые рассматриваются в качестве одного из важнейших факторов укрепления позитивных связей между осужденными, их семьями и обществом.

При нарушении осужденным условий отбывания назначенной меры наказания, не связанной с лишением свободы (без изоляции от обшества), она может быть изменена или отменена.

Описанные групгы международных стандартов создают в совокупности примерную модель организации исполнения наказания без изоляции от общества, реализация которой может стать эффективным средством усовершенствования национальной уголовно-исполнительной политики государств.

В связи со вступлением Российской Федерации в Совет Европы важное значение для нашей уголовно-исполнительной политики приобретает последовательная реализация европейских стандартов организации регулирования исполнения наказания осужденных. К документам, содержащим европейские стандарты рассматриваемого профиля, в частности, следует отнести:

- Европейскую Конвенцию о надзоре за условно осужденными или условно освобожденными правонарушителями от 30 ноября 1964 года;

- Европейскую Конвенцию о защите прав и основных свобод человека 1950 г.;

- Европейскую Конвенцию по предупреждению пыток, бесчеловечного или унижающего достоинство обращения или наказания;

- Европейские пенитенциарные правила, объявленные Рекомендацией № R(87)3 Комитета министров Совета Европы от 12 февраля 1987 года;

- Резолюцию Комитета министров Совета Европы от 9 марта 1976 года «О некоторых мерах наказания, альтернативных лишению свободы»;

- Резолюцию Комитета министров Совета Европы о труде заключенных от 18 сентября 1975 года и др.

Европейские стандарты развивают и детализируют универсальные стандарты ООН, учитывая особенности стран, входящих в Совет Европы. Анализируемые ниже законоположения и подзаконные правила, действующие в России в рассматриваемой сфере, в принципе соотносятся как с международными, так и с европейскими стандартами. 


\section{Российские правовые нормы о наказанных без изоляции от общества и порядке их исполнения ${ }^{10}$}

Как известно, трудовые отношения возникают и прекрашаются на основе и с учетом трудового договора между работодателем и работником ${ }^{11}$, который закпочается на равноправной добровольной основе. В то же время действующее уголовное законодательство в определенных случаях и за определенные рассматриваемые ниже преступления ставит работодателя в такое положение, когда он должен или принять на работу (обязательные работы), или не увольнять работника (исправительные работы по месту имеющихся трудовых отношений), или прекратить трудовые правоотношения с работником в связи с требованием законодателя, выраженном в уголовно-правовой норме. Все указанные обстоятельства так или иначе имеют место в рамках трудовых отношений, когда ни одна из сторон этих отношений не имеет ясно выраженной воли к этим отношениям. К тому же, надо прямо сказать, такие отношения являются в известной мере бременем для работодателя. Тем не менее порядок установления таких трудовых отношений работодателю, равно как и осужденному, необходимо знать.

Разумеется, указанные специфические трудовые отношения изначально возникают на основании обвинительного приговора суда. Такой приговор, вступивший в законную силу, составная и основная часть которого представляет собой назначенное осужденному наказание, обязателен для всех предприятий, организаций и учреждений, а также должностных лиц и граждан и подлежит исполнению ${ }^{12}$ (ст. 358 УПКРФ).

Сущностью и содержанием наказания как особой формы государственного принуждения является кара, поэтому под его исполнением понимается урегулированный нормами уголовно-исполнительного права порядок применения мер государственного принуждения (кары) - комплекса ограничений прав и свобод осужденного.

\footnotetext{
${ }^{10}$ В настоящей статье не рассматриваются вопросы, касающиеся контроля со стороны уголовно-исполнительных инспекций за условно осужденными и за поведением осужденньг женщин, которым судом предоставлена отсрочка отбьтия наказания.

"Об этом, например, см.: Анисимов Л.Н. Трудовой договор и индивидуальные трудовые споры: Учебное пособне. М., 2004; он же: Трудовой договор. Заключение, изменение и прекращение. Практическое пособие. М., 2005.

${ }^{12}$ О понятии и правовом регулированин исполнения (отбывания) наказания и применении исправительного воздействия подробнее, например, см.: Уголовно-исполнительное право России / Под ред. проф. В.И. Селиверстова. М., 2001. С. 85-96.
} 
Кара представляет собой лишение человека его определенных прав и интересов, уменьшение их объема либо введение особого порядка их осуществления. В нашем контексте осужденному без изоляции от общества установлен в виде наказания определенный порядок в трудовых отношениях.

Иногда возникает вопрос о том, не являются ли рассматриваемые меры принуждения, в частности, наказание в виде обязательных работ, принудительным трудом, противоречащим конституционному принципу свободы труда. Она гарантируется запрешением принудительного труда в соответствии с частью 2 ст. 37 Конституции РФ и ст. 4 Трудового кодекса РФ.

Свобода труда заключается в том, что каждому обеспечено право свободно распоряжаться своими способностями к труду, то есть добровольно и самостоятельно решать вопрос о своей деятельности, начиная с решения принципиального вопроса: заниматься трудовой деятельностью или нет. Что же касается запрещения принудительного труда, то положения ст. 4 ТК РФ основаны на нормах международного права в сфере труда и рекомендации Международной Организации Труда (МOT). Так, в ст. 8 Международного пакта о гражданских и политических правах говорится о том, что никто не должен привлекаться к принудительному труду.

Значительное внимание к проблемам принудительного труда уделено в актах МОТ. Этому вопросу посвящены две конвенции (№ 29 и № 105) и ряд рекомендаций. Конвенция МОТ № 29 (1930 г.) обязывает государства упразднить применение труда во всех его формах. Указанное применение принудительного труда должно подлежать наказанию как уголовное преступление. В конвенции (ст. 2) под принудительным трудом понимается любая работа или служба, требуемая от какого-либо лица под угрозой какого-либо наказания и для которой это лицо не предложило своих услуг.

Приведенное определение принудительного труда не является, однако, всеобъемлющим. В ряде случаев, согласно конвенции, принуждение к труду правомерно, но при определенных условиях и ограничениях. К таким случаям относятся:

- работа, требуемая в силу закона об обязательной военной службе и применяемая для работ чисто военного характера;

- работа, являющаяся частью обычных гражданских обязанностей; - работа, требуемая в силу судебного приговора, при условии, что 
эта работа будет производиться под надзором и контролем государственных властей и указанное лицо не будет передано в распоряжение частных лиц или хозяйственных товариществ;

- работа, необходимость которой вызвана чрезвычайными (непреодолимыми) обстоятельствами;

- мелкие работы для пользы коллектива, если его представители выскажут мнение о целесообразности таких работ.

Конвенция МОТ № 105 (1957 г.) ужесточает запрещение принудительного труда и расширяет круг обязательств государств по устранению принудительного труда. Специально перечислены виды труда, которые квалифицируются как принудительный труд:

- в качестве средства политического воздействия, или воспитания, или меры наказания за наличие политических взглядов или идеологических убеждений, противоположных установленной политической социальной или экономической системе;

- в качестве метода мобилизации использования рабочей силы для нужд экономического развития страны;

- в качестве средства для поддержания трудовой дисциплины;

- в качестве средства наказания за участие в забастовке.

К изложенному необходимо добавить, что международные акты о правах человека и обращения с осужденными признают обязательность труда осужденных (п. 2 ст. 71 Минимальных стандартных правил обращения с осужденными). Международный пакт о гражданских и политических правах 1966 г. (п. 3 ст. 8) не относит работу, которую выполняют осужденные лица, к категории принудительного или обязательного труда.

Применительно к рассматриваемому нами вопросу из сказанного выше можно сделать совершенно определенный вывод о том, что выполняемая по приговору суда в качестве уголовного наказания работа не считается принудительным трудом. В УИК РФ общественно полезный труд рассматривается как обязанность осужденных (ч. 2 ст. 103, ч. 1 ст. 53 , ч. 1 ст. 164$)$.

Следует также отметить, что уголовно-исполнительное наказание (ч. 2 ст. 1, ч. 2 ст. 2 УИК РФ) для обозначения мер принуждения наряду с термином «исполнение» употребляет термин «отбывание» наказания. Эти термины, хотя и отражают единый процесс принудительного воздействия на осужденного, но обращены к различным субъектам и участникам уголовно-исполнительных отношений, так 
или иначе связанных с трудовыми отношениями по рассматриваемой ниже категории осужденных без изоляции от общества.

Термин «исполнение» наказания относится к соответствующим учреждениям, организациям и органам, которые в своей деятельности должны реализовать весь комплекс установленных приговором суда правоограничений, а также обеспечить предоставляемые осужденным права и выполнение ими возложенных на них обязанностей в течение всего срока наказания.

Термин «отбывание» наказания касается осужденных, которые должны в соответствии с приговором суда и предписаниями уголовноисполнительного законодательства выполнять возложенные на них обязанности, воздерживатъся от действий, запрешенных нормами права, осуществлять свои права.

\section{Исполнение наказания в виде лишения права занимать определенные должности или заниматься определенной}

\section{деятельностью}

В соответствии со ст. 47 Уголовного кодекса Российской Федерации (УК РФ) в качестве наказания предусмотрено лишение права занимать определенные должности или заниматься определенной деятельностью. Оно может быть основным или дополнительным. В качестве основного наказания оно может применяться на срок от одного года до пяти лет, в качестве дополнительного - до трех лет. Данное наказание состоит в запрешении занимать должности на государственной службе, в органах местного самоуправления либо заниматься профессиональной или иной деятельностью. В качестве дополнительного наказания оно может назначаться и в случаях, когда оно не предусмотрено в санкции соответствующей статьей Особенной части УК РФ, если с учетом характеристики и степени общественной опасности совершенного преступления и личности виновного суд признает невозможным сохранение за ним права занимать определенные должности или заниматься определенной деятельностью ${ }^{13}$.

${ }^{13}$ В Трудовом кодексе РФ (ст. 84) закреплено положение о том, что трудовой договор прекращается вследствие нарушения установленных Кодексом или иным федеральным законом обязательных правил его заключения, в том числе в случае нарушения притовора суда о лишении конкретного лица права занимать определенные должности или заниматься определенной деятельностью; об этом, например, см.: Анисимов Л.Н., Анисимов А.Л. Трудовые отношения и внутренний трудовой распорядок. М.: Изд-во «Юридическая литература», 2005. С. 258-260. 
Под определенными должностями понимается круг должностей, обозначенных нормативно или обладающих идентификационными признаками, которые позволяют достоверно и точно выявить содержание судебного запрета. Суд не вправе обозначить запрет занимать должности таким образом, чтобы допускалось расширительное толкование этого запрета и не представлялось возможности тем или иным должностным лищам произвольно ограничивать право граждан на выбор рода деятельности, профессии в соответствии со ст. 37 Конституции РФ.

Что же касается запрещения заниматься определенной профессиональной деятельностью, то такой запрет может распространяться на вид деятельности, требующий профессиональной подготовки, либо деятельности, включающей в себя виды работ, требующие специальной подготовки или позволяющие совершать определенные действия или принимать решения на основе нормативно-правовых актов. Широкий неопределенный запрет неправомерен, так как он не соответствовал бы целям наказания.

Рассматриваемый вид наказания оказывает определенное психологическое воздействие на осужденного, сушественно ограничивает его права и возможности, способствует «очищению» государственной службы и иных видов деятельности от лиц, наносящих серьезный ущерб обществу и отдельным гражданам.

Исполнение наказания в виде лишения права занимать определенные должности или заниматься определенной деятельностью, назначенного как в качестве основного, так и дополнительного вида наказания к штрафу, обязательным работам или исправительным работам, а также при условном осуждении осушествляет инспекция по месту житетьства.

Прежде всего отметим, что администрация учреждения, в котором отбывает основной вид наказания лищо, осужденное также к дополнительному наказанию в виде лишения права занимать определенные должности или заниматься определенной деятельностью, не может привлекать осужденного к работам, выполнение которых ему запрещено. За двадцать дней до окончания срока, а в случае условнодосрочного освобождения или замены наказания более легким - в день освобождения исправительное учреждение направляет в инспекцию по избранному им месту жительства копию приговора суда или выписку из такового, а также справку на осужденного с указанием уста- 
новочных данных, даты освобождения, родственных и других близких связей.

При получении из паспортно-визовой службы органа внутренних дел информации о регистрации осужденного, освобожденного из мест лишения свободы, имеющего неотбытую часть рассматриваемой дополнительной меры наказания и прибывшего не по месту первоначально избранного им места жительства, инспекция запрашивает копию приговора суда у инспекции, обслуживающей территорию первоначально избранного места жительства осужденного, и контролирует поступление копин приговора суда.

В главе I рассматриваемой Инструкции определен следующий порядок оформления документов на осужденньг.

Инспекция получает копию приговора (определения, постановления) суда, регистрирует ее в журнале входящих документов и журнале учета осужденных ${ }^{14}$, а затем оформляет указанные ниже документы и направляет осужденному уведомление о необходимости явки в инспекцию.

В таком же порядке регистрируются личные дела, поступившие из других инспекций в связи с изменением осужденными места работы и жительства.

В день поступления копии приговора (определения, постановления) суда инспекция направляет в суд, вынесший приговор (определение, постановление), извещение о принятии его к исполнению.

Кроме того, после регистрации копии приговора (определения, постановления) суда на каждого осужденного заводится личное дело, заполняется контрольно-сроковая ${ }^{15}$ и сторожевая ${ }^{16}$ карточка.

Сторожевая карточка направляется в паспортно-визовую службу органа внутренних дел для контроля за снятием осужденного с регистрационного учета и информирования инспекции об изменении его места жительства.

Контрольно-сроковая карточка помещается в картотеку.

В соответствии с пунктом 18 Инструкции о постановке осужденного на учет инспекция направляет сообщение начальнику органа внут-

\footnotetext{
${ }^{14}$ На каждую категорию осужденных заводится отдельный журнал.

${ }^{15}$ В этой карточке указываются окончание срока наказания (испытательного срока, отсрочки отбывания наказания), номер личного дела и дата постановки на учет в инспекции.

${ }^{16}$ В данной карточке обозначены окончание и отметки о6 изменении срока наказания, по какой ст. УК РФ осужден, срок наказания и дата снятия с регистрационного учета.
} 
ренних дел для организации проведения участковым уполномоченным милиции профилактических мероприятий и участия в контроле за поведением осужденного, а в отношении несовершеннолетнего осужденного инспекция направляет сообщение начальнику органа внутренних дел для организации проведения сотрудником подразделения по делам несовершеннолетних индивидуальной профилактической работы.

При постановке на учет осужденного (гражданина России) призывного возраста соответствующее сообщение инспекция направляет в военкомат (п. 19 Инструкции).

В день явки в инспекцию осужденному разъясняются порядок и условия отбывания наказании, его права и обязанности, уточняются и проверяются анкетные данные, сведения о близких родственниках и другие вопросы, имеющие значение для осушествления контроля за исполнением осужденным требований приговора. По окончании беседы у осужденного отбирается подписка ${ }^{17}$ и составляется справка по результатам беседы, которые приобщаются к его личному делу.

В целях обеспечения исполнения приговора суда инспекция в течение трех рабочих дней:

1) устанавливает место работы осужденного и направляет в адрес администрации организации копию приговора суда и извещение ${ }^{18}$. В последнем, в частности, разъясняется, что в соответствии с ч. 2 ст. 34 УИК РФ организация, в которой работает осужденный, обязана: а) не позднее трех дней после получения копии приговора суда и получения извещения инспекчии освободить осужденного от должсноти, которую он лишен права занимать, или запретить заниматься определенной деятельностью и направить в инспекцию сообщение об исполнении требований приговора; б) представлять по требованию инспекции документы, связанные с исполнением наказания; в) в случаях изменения или прекращения трудового договора с осужденным в трехдневный срок сообчить об этом в инспекцию; г) в случае увольнения из организачии осужденного, не отбывшего наказание, внести в его трудовую книжку запись о том, на каком основании, на какой срок и какую должность он лишен права занииать или какой деятельностью лищен права заниматься;

${ }^{17}$ В подписке осужденный дает обязательство исполнять требования приговора суда, представљть по требованию инспекции документы, связанные с отбыванием рассматриваемого наказания, сообщать в инспекщию о месте работы, его изменении иши увольнении с работы, а также об изменении места жительства.

${ }^{18}$ В извешении разъясняются в соответствии со ст. 35 УИК РФ обязанности органа, правомочнго аннулировать разрешения на занятие определенной деятельностью. 
2) направляет копию приговора суда или заверенную выписку из него и извещение в орган, правомочный аннулировать разрешение на занятие определенным видом деятельности ${ }^{19}$;

3) в отношении осужденного, лишенного права занимать должности в сфере экономической деятельности, направляют сообщение в соответствующую службу органа внутренних дел. В этом сообщении также высказывается просьба организовать контроль за исполнением осужденным требований приговора суда и информировать инспекцию о допушенных им нарушениях.

В течение месяца после постановки осужденного на учет инспекция осуществляет проверку выполнения требований приговора суда администрацией организации, в которой он работает, и органом, правомочным аннулировать разрешение на занятие определенной деятельностью. О результатах проверки составляется справка, которая приобщается к личному делу осужденного.

При получении сообщения об увольнении осужденного с прежнего места работы инспекция в месячный срок с момента его получения:

- устанавливает новое место работы осужденного;

- направляет по новому месту работы копию приговора суда и аналогично указанному выше извещение;

- проверяет по новому месту работы осужденного наличие в его трудовой книжке записи, соответствующей приговору суда, и устанавливает его должность (род деятельности).

В отношении осужденного, не работающего на момент постановки на учет, инспекция, используя информацию органа службы занятости и участкового уполномоченного милиции, осуществляет контроль за его трудоустройством.

В целях последующего контроля инспекция не реже одного раза в шесть месяцев проверяет исполнение приговора суда администрацией организации и осужденным.

В случае если обязанные лица не исполняют вступивший в законную силу приговор (решение) суда или иной судебный акт о лишении права занимать определенные должности или заниматься определенной деятельностью, инспекция направляет в их адрес представление. При игнорировании последнего инспекция направляет соответствующие материалы в прокуратуру для решения вопроса о привлечении

\footnotetext{
${ }^{19}$ Количество лицензируемьх видов деятельности составляет сегодня около полутора сотнен (Российская газета. 2005. 21 нюня).
} 
виновных должностных лиц к уголовной ответственности в соответствии со ст. 315 («Неисполнение приговора суда, решения суда или иного судебного акта») УК РФ. По этой статье несут ответственность представители власти, государственные служащие органов местного самоуправления, а также служащие государственного или муниципального учреждения, коммерческой или иной организации, если они злостно не исполняли вступившие в законную силу приговор суда или иной судебный акт, а равно воспрепятствовали их исполнению. Злостным следует считать неувольнение осужденного с должности, которую он не имел права занимать, после предупреждения, сделанного сотрудниками уголовно-исполнительной инспекции.

В практическом плане виновным в таком преступлении может быть как руководитель организации, так и руководитель кадровой службы, который готовит соответствующий приказ, проверяет документы, вносит запись об осуждении в трудовую книжку.

В срок рассматриваемого наказания не засчитывается время, в течение которого осужденный занимал запрешенные для него должности либо занимался запрешенной для него деятельностью.

По истечении срока наказания осужденный снимается с учета в порядке, предусмотренном в главе VIII рассматриваемой Инструкции.

\section{Исполнение наказания в виде обязательных работ}

Обязательные работы в качестве уголовного наказания появились в уголовном законодательстве Российской Федерации как результат предлагаемого международным сообществом поиска способов спектра наказаний без изоляции от общества.

По российскому уголовному законодательству (ст. 49 УК РФ) сущность обязательных работ заключается в выполнении осужденным в свободное от основной работы или учебы время бесплатных общественно полезных работ, вид которых определяется органами местного самоуправления. Обязательные работы назначаются на срок от шестидесяти до двухсот сорока часов и отбываются не свыше четырех часов в день. От количества, характера и условий осушествления обязательного труда осужденный уклоняться не вправе.

Рассматриваемый вид наказания применяется как ко взрослым, так и к несовершеннолетним (в возрасте от 14 лет) преступникам. При применении к последним (ст. 88 УК РФ) они назначаются на срок 
от 40 до 160 часов и отбываются в возрасте до 15 лет не свыше двух, а в возрасте от 15 до 16 лет-не свыше трех часов в день.

Законодатель установил в ч. 3 ст. 49 УК РФ возможность и порядок замены этого вида наказания в случае злостного уклонения осужденного от отбывания обязательных работ ограничением свободы или арестом.

Злостно уклоняющимся от обязательньх работ признается осужденный (ст. 30 УИК):

- более двух раз в течение месяца не вышедший на обязательные работы без уважительных причин;

- более двух раз в течение месяца нарушивший трудовую дисциплину;

- скрывающийся в целях уклонения от отбывания наказания.

В ч. 4 данной статьи законодатель установил перечень лиц, к которым этот вид наказания не применяется. К ним относятся: инвалиды первой или второй группы; беременные женщины, женшины, имеющие детей в возрасте до восьми лет; женщины, достигшие пятидесятилетнего возраста; мужчины, достигшие шестидесятилетнего возраста, а также военнослужашие, проходящие воинскую службу 'по призыву.

Согласно ст. 45 УК РФ обязательные работы применяются лишь в качестве основного вида наказания. Данное обстоятельство свидетельствует о том, что законодатель относит обязательные работы к достаточно строгим наказаниям. Вместе с тем в уголовном законодательстве обязательные работы предусмотрено применять в качестве наказания за преступления небольшой тяжести. Например, умышленное причинение легкого вреда здоровью (ст. 115 УК РФ), оставление в опасности (ст. 125 УК РФ), оскорбление (ст. 130 УК РФ), злостное уклонение от уплаты средств на содержание детей или нетрудоспособных родителей (ст. 157 УК РФ), злостное уклонение от погашения кредиторской задолженности (ст. 177 УК РФ) и др.

Можно сказать, что социальное назначение обязательных работ состоит в том, чтобы оказать профилактическое воздействие на менее опасные для обшества категории правонарушителей, не отрывая их при этом от привычной работы, учебы или иной общественно полезной деятельности.

Как уже отмечалось, обязательные работы исполняются инспекциями по месту жительства осужденного. 
Осужденный к обязательным работам привлекается к отбыванию наказания не позднее 15 дней со дня поступления в уголовно-исполнительную инспекцию распоряжения суда с копией приговора или иного судебного акта (п. 40 Инструкции). По получении судебных документов и их регистрации оформляются соответствующие документы по рассмотренным выше правилам главы I Инструкции, и осужденному направляется письменное уведомление о необходимости явки в инспекцию.

К этому следует добавить, что на каждого осужденного заводится определенная учетная карточка, в которой ведется учет отработанного осужденным времени и нарушений трудовой дисциплины ${ }^{20}$.

В день явки осужденного после проведения с ним разъяснительной беседы о порядке и условиях отбывания наказания ему выдается соответствующее предписание для отбывания обязательных работ. При этом учитывается его место жительства, график основной работы или учебы, состояние здоровья, возрастные способности и профессиональные навыки ${ }^{2 !}$.

В организацию, в которой осужденный будет отбывать наказание, инспекция направляет копию приговора (решения, постановления) и извещение. В последнем указываются данные, по какой статье УК РФ осужденный привлечен к утоловной ответственности в виде обязательных работ, на какой срок, установленный в часах, и когда он должен приступить к работе. При этом высказывается просьба обеспечить: издание приказа о приеме осужденного на работу (в соответствии с приговором суда); ознакомление его под расписку с правилами внутреннего трудового распорядка организации, техники безопасности и производственной санитарии; ведение ежедневного табеля с отражением количества отработанных часов и ежемесячное направление его копии в инспекцию; информирование инспекции о невыходе осужденного на работу и допущенных им нарушениях трудовой дисциплины и др.

В соответствии со ст. 28 УИК РФ на администрации организаций, в которых осужденные отбывают работы, возлагаются: контроль за выполнением осужденными определенных для них работ, уведомление

\footnotetext{
20 Учетная карточка помещается в картотеку персонального учета осужденных.

${ }^{21}$ Предоставление осужденному очередного ежегодного отпуска по основному месту работы не приостанавливает исполнение наказания в виде обязательных работ (п. 46 Инструкции).
} 
уголовно-исполнительной инспекции о количестве проработанных часов или уклонении осужденных от отбывания наказания. В случае причинения увечья, связанного с выполнением обязательных работ, возмещение вреда осужденному производится в соответствии с дейсгвуюшим трудовым законодатепством Российской Федерации.

В случае признания осужденного инвалидом первой или второй группы инспекция направляет в суд соответствуюшее представление о его досрочном освобождении от даґнейшего отбывания наказания, а при наступлении беременности осужденной - представление об отсрочке ей отбывания наказания со дня предоставления отпуска по беременности и родам.

Для осуществления контроля за исполнением обязательных работ инспекция:

- не реже одного раза в месяц осуществляет выходы на объекты для проверки поведения осужденных по месту работы;

- не реже одного раза в течение срока наказания проверяет осужденного по специальным учетам органов внутренних дел на предмет выявления новых правонарушений и привлечения к уголовной ответственности.

- Началом срока отбывания обязательных работ является день выхода осужденного на работу.

Срок обязательных работ, как уже отмечалось, исчисляется в часах, в течение которых осужденный отбывал обязательные работы.

\section{Исполнение наказания в виде исправительных работ}

Исправитешыные работы относятся к чисту наказаний, которые представлены в санкциях значительной части статей Уголовного кодекса РФ. При этом отбывание исправительньх работ неразрывно связано с трудовой деятепьостыю, поэтому данный вид наказания не может быть назначен нетрудоспособному. Специалисты по уголовно-исполнительному праву считают «достоинство» рассматриваемой меры наказания в том, что осужденный к исправительным работам продолжает трудиться на той же должности, что и до осуждения ${ }^{22}$.

В ст. 50 УК РФ определено, что исправительные работы устанавливаются на срок от двух месяцев до двух лет. «Исправительные работы назначаются осужденному, не имеющему основного места работы, ${ }_{22}$ См.: Уголовно-исполнительное право России / Под ред. проф. В.И. Селиверстова. M., 2001.C. 237. 
и отбываются в местах, определяемых органом местного самоуправления по согласованию с органом, исполняющим наказания в виде исправительньгх работ, но в районе места жительства осужденного» (ч. 1).

В рассматриваемой Инструкции определен порядок исполнения наказания в виде исправительных работ ${ }^{23}$.

Исправительные работы отбываются в местах, определяемых органом местного самоуправления по согласованию с инспекцией в районе места жительства (п. 60 Инструкции).

Осужденный к исправительным работам направляется инспекцией для отбывания наказания не позднее 30 дней со дня поступления в инспекцию соответствующего распоряжения суда с копией приговора (определения, постановления).

По получении указанных документов, наряду с выполнением требований по учету осужденного, последнему направляется уведомление о явке в инспекцию, где ему выдается предписание для отбытия исправительньх работ.

В организацию, в которой будет работать осужденный, инспекция направляет копию приговора (определения, постановления) суда, извещение о сущности уголовного наказания и бланк расчетных сведений о работе осужденного.

В соответствии со ст. 40 УИК РФ установлены следующие требования для рассматриваемой категории осужденных:

- осужденные к исправительным работам обязаны соблюдать порядок и условия отбывания наказания, добросовестно относится к труду, являться в уголовно-исполнительную инспекцию по ее вызову;

- из заработной пшаты осужденного производятся удержания в размере, установленном приговором

- в период отбывания исправитешных работ осужденным запрещается увольнение с работы по собственному желанию без разрешения в письменной форме уголовно-исполнительной инспекции;

- осужденный не вправе отказаться от предложенной ему работы;

- осужденный обязан сообщать в инспекцию об изменении места работы и места жительства в течение 10 дней;

23Этот порядок разработан на основе ст. 50, 72, 81 УК РФ; ст. 107, 108, 399 УПК РФ; ст. 23, 39-46, 173, 175 УИК РФ; ст. 138 ТК РФ.

${ }^{24}$ Удержание из заработной платы в доход государства от 5 до 20\% заработка является основным карательным элементом наказания. На практике суды ориентируются главным образом на максимальный процент удержаний. 
- в период отбывания исполнительных работ ежегодный оплачиваемый отпуск продолжительностью 18 рабочих дней предоставляется администрацией организации, в которой работает осужденный, по согласованию с инспекцией. Другие виды отпусков, предусмотренные российским трудовым законодательством, предоставляются осужденным на общих основаниях.

В свою очередь, согласно ч. 1 ст. 43 УИК РФ, на администрацию организации, в которой работает осужденный к исправительным работам, возлагаются следуюшие обязанности:

- правильное и своевременное удержание соответствуюших сумм из заработной платы и перечисление этих сумм «в установленном порядке»;

- контроль за поведением осужденного на производстве и содействие инспекции в проведении с ним воспитательной работы;

- соблюдение условий отбывания наказания;

- уведомление инспекции о примененных к осужденному мерах поощрения и взыскания, а также предварительное уведомление о переводе осужденного на другую должность или его увольнение с работы в установленном порядке ${ }^{25}$.

.Согласно предписаниям Инструкции (Приложение № 25), удержание из заработной платы работника необходимо производить со дня его выхода на работу (или со дня получения предписания и копии приговора суда, если исправительные работы назначены по месту работы осужденного) и перечислять ежемесячно в день выдачи заработной платы в доход федерального бюджета в порядке, установленном бюджетным законодательством. Расчетные сведения о перечислении удержаний с осужденного с указанием номера и даты платежного поручения должны ежемесячно высылаться в уголовно-исполнительную инспекцию.

Удержания производятся по основному месту работы заключенного за каждый отработанный месяц, включая все виды дополнительных выплат, в том числе денежные премин, предусмотренные системой оплаты труда, если они не носят характер единовременного вознаграждения. При увольнении удержания производятся за отработанную часть месяца.

${ }^{25}$ Неисполнение перечисленных обязанностей должностными лицами организации влечет уголовную ответственность по ст. 315 УК РФ. 
В сложившейся практике возник вопрос об определении заработка осужденных, работающих в различных коммерческих структурах, где зарплата выплачивается нерегулярно, а по мере получения дохода в связи с выполнением той или иной работы, завершением коммерческой сделки и т.п. Общее правило заключается в том, что должен учитываться весь доход по основному месту работы, полученный за время отбывания наказания, или та часть дохода, которая приходится на время отбывания наказания.

Удержания производятся без исключения из заработной платы осужденного налогов и других платежей, а также независимо от наличия к нему претензий по исполнительным документам. В соответствии с ч. 3 ст. 138 Трудового кодекса РФ общий размер удержаний из заработной платы не может превышать $70 \%$.

При производстве удержаний учитывается денежная и натуральная часть заработной платы. И в этой связи напомним, что согласно действующей на территории Российской Федерации Конвенщии МОТ «Об охране заработной платы» (1949 г.) законодательство страны и коллективные договоры могут разрешать частичную выплату заработной платы натурой в тех отраслях промышленности или профессиях, где такая выплата является обычной и желательной. В ч. 2 ст. 131 Трудового кодекса РФ на этот счет сказано, что по письменному заявлению работника оплата труда может производиться и в иных формах, не противоречащих законодательству России и ее международным договорам. Доля заработной платы, выплачиваемой в неденежной форме, не может превышать 20\% от общей суммы заработной платы.

В этом контексте работодатель должен знать и о другом: что натуральная часть дохода осужденного к исправительным работам остается в распоряжении организации, а ее стоимость по государственным закупочным (рыночным) ценам перечисляется в доход федерального бюджета. Удержания из доходов в их натуральной части производятся по мере ее поступления и при окончательном расчете.

Удержания не производятся из пособий, получаемых осужденным в порядке социального обеспечения и сощиального страхования; выплат единовременного характера (в том числе компенсации за неиспользованный отпуск), за исключением ежемесячных страховых выплат по обязательному социальному страхованию от несчастных случаев на производстве и профессиональньх заболеваний; из заработной платы, начисленной за дни, проработанные сверх графика работы, выход- 
ного пособия; из сумм, выплачиваемых в качестве компенсации за расходы, связанные с командировками, переводами, за использование лично приналлежащего работнику инструмента, транспорта, за невыданную спецодежду, спецобувь, иных компенсационных выплат .

Пособие по временной нетрудоспособности осужденного исчисляется из его заработной платы за вычетом удержаний в размере, установленном приговором суда.

В случае ухудшения материального положения осужденного инспекция разъясняет осужденному его право обращения в суд с ходатайством о снижении размера удержаний из его заработной платы.

Сотрудники уголовно-исполнительной инспекции не реже одного раза в шесть месяцев проверяют правильность удержаний из заработанной платы осужденных. О результатах проверки составляется акт в двух экземплярах, один из которых остается в организации, а второй с отметкой представителя администрации организации об ознакомлении с актом хранится в инспекции и используется для контроля за устранением недостатков.

Срок исправительных работ исчисляется в месяцах и годах, в течение которых осужденный работал и из его заработной платы производились удержания. В каждом месяце установленного срока наказания количество дней, отработанных осужденным, должно быть не менее количества рабочих дней, приходящихся на этот месяц.

В срок отбывания наказания не засчитывается:

- время, в течение которого осужденный не работал по уважительным причинам (болезнь, любые виды отпусков и т.д.);

- время болезни, вызванной алкогольным, наркотическим или токсическим опьянением или действиями, связанными с ними;

- время отбывания административного взыскания в виде ареста, а также время содержания под домашним арестом или под стражей в порядке меры пресечения по другому делу в период отбывания наказания.

Если осужденный не отработал срока исполнительных работ, то, разумеется, отбывание исправитепьых работ продолжается до полной отработки осужденным установленного приговором суда срока.

В отношении осужденного, злостно уклоняющегося от отбывания наказания, инспекция направляет в суд представление о замене исправительных работ другим видом наказания в соответствии с частью третьей ст. 50 УК РФ. 